\title{
The European Investment Crisis
}

Investment expenditure collapsed in Europe in the aftermath of the global financial crisis. By 2013, total investment across the EU had fallen about 20 per cent from its peak in 2008. In the most crisis-hit countries, investment had fallen by more than 40 per cent. During the crisis, the decline of investment in Europe has been double that in the US and Japan. By the beginning of 2014, investment started to recover in Europe but is still growing at a slower pace than nominal GDP. In contrast, investment as a share of GDP has been recovering since 2010 in both the US and Japan.

Both private and public investment in Europe has been affected. In the first phase of the crisis (up until 2009/2010) public investment remained relatively stable as a percentage of GDP. A correction occurred later and was particularly visible in those countries that undertook major fiscal consolidation, namely the EU periphery and the new member states. In the core EU countries, public investment as a percentage of GDP is today slightly above the pre-crisis levels. It seems clear that in a number of EU countries the need for strong fiscal consolidation has limited the scope for investment-based countercyclical measures.

The EIB analysed the causes of the collapse in investment in Europe in its 2013 report "Investment and Investment Finance in Europe". Episodes of over-investment lie at the heart of the investment crisis. Overcapacity has contributed to low returns across the EU, discouraging investment in some countries. However, the report suggests that the most important immediate cause of the collapse in investment and subsequent stagnation was uncertainty about the world economy and the resolution of the European financial and sovereign debt crisis. Faced with uncertainty about policy changes or the wider economic situation, investors adopted a "wait-and-see" attitude, postponing major investment until uncertainty dissipated.

Interestingly, access to finance is not a prime driver of the EU's private investment crisis. On the whole, non-financial corporations have actually increased their savings through cost-cutting and lower interest and dividend payments throughout the crisis. The corporate sector had access to the funds it needed for investment but, rather than investing, firms have become net savers and ultimately net lenders, particularly to the government sector. However, it is also true that the crisis has led to a fragmentation of EU financial markets. It is the market segments most dependent on bank lending that have faced the greatest constraints. Heightened risk aversion and the scalingback of alternatives such as SME securitisation and venture capital have made things worse. Bank deleveraging correlates most strongly (and negatively) with investment by smaller, unlisted firms that tend to rely on bank finance. Overall, the supply of finance remains a serious constraint for some firms and sectors in some countries. Hardest hit are SMEs and young innovative firms.

Following the double-dip recession, the EU's economic outlook has finally improved, but the economic scenario remains extremely fragile. The EU Commission's spring forecasts point to growth of around 1.6 per cent in 2014. Growth differentials, however, will persist, while most recent leading indicators point to a very sluggish recovery. The debt sustainability crisis in Europe has stabilised, but the implementation of the ambitious reform agendas at the national and EU levels remains a priority. The EU's financial sector remains fragmented. New extraordinary measures implemented by the ECB, the creation of the Banking Union, the finalisation of the asset quality review and stress tests, and the resulting incentives for banks to recapitalise are expected to create the basis for a more sustainable financial market. Re-emerging external risks in the form of an economic slowdown in emerging market economies and new geopolitical tensions weigh on the downside.

As the EU exits a crisis-fighting phase, attention needs to be shifted towards Europe's long-term challenges - sustainable growth and competiveness. The EU Commission's estimates for the EU's potential growth have been strongly revised downwards in recent years, from a pre-crisis two per cent potential growth to some one per cent potential growth in 2014. The EU's investment 
crisis combines with an EU employment crisis and a clear long-term competitiveness crisis. The EU's loss of competitiveness is not a new phenomenon. EU productivity growth has fallen behind that in the US since the mid-1990s. Europe has not kept pace with other leading economies, and its ability to compete has declined. The economic and financial crisis significantly aggravated this trend. The EU employment crisis has generated the risks of a "lost generation" and depletion of human capital. The EU investment crisis means obsolescence of capital, losses in terms of technological advances and potential constraints affecting an effective reallocation of resources.

Economic policy in the EU must complement short-term crisis-fighting with a long-term focus: to restore the EU's competitiveness. The competitiveness of EU economies depends on the capacity of firms and industries to drive and adapt to change through innovation, raising productivity, and establishing a presence in key strategic sectors. Restoring competitiveness is at the heart of ensuring long-term sustainable economic recovery throughout the EU. This means recreating an enabling environment for efficient resource allocation, innovation, modernisation and productivity growth by EU firms. Structural reforms are key, as well as investment enablers.

Member states must proceed with structural reforms and create an environment that is conducive to investment. Flexibility on the part of each and every economy and the reallocation of resources towards more productive uses is necessary to enable the EU to compete in the international arena. At the EU level, efforts to address the inefficiencies of the EU's internal market should be pursued. Such inefficiencies have so far made it difficult to exploit the full benefits of the EU's integration project. The European Parliament study "Mapping the Cost of Non-Europe 2014-19" brings together a series of estimates of the efficiency gains that could be achieved, weighting overall for some five per cent of the EU's GDP.

To sustain high income levels, Europe needs to excel in high value-added activities within globalised systems of production. This capacity depends in turn upon certain enabling factors, including targeted investment in areas crucial for EU competitiveness. Investment in those areas - whether in R\&D in key sectors and technologies, in education or in the renewal and expansion of infrastructure - has fallen far behind what we need to preserve the EU's competitive position. A number of gaps currently undermine Europe's competitiveness, as well as strategic sectors where we need to make sure we keep our lead: the R\&D gap, the financing gap for young innovative firms, the need to accelerate firms' investment in modernisation, the need to invest more in human capital, the backlog of investment in strategic infrastructure, including energy and energy efficiency. Well-targeted public intervention in areas crucial for Europe's long-term competitiveness could be a response. It should clearly address market failures and catalyse private sector investment.

The plan for the new Commission, led by Juncker, has presented an Agenda for Jobs, Growth, Fairness and Democratic Change. The agenda's aims include an investment plan that takes as its starting point much better use of public investment (EU funds and the EIB), with the objective of catalysing private investment. Juncker has mentioned that "better planning and simplification should allow to mobilise up to EUR 300 billion in additional public and private investment in the real economy over the next three years. ... The preparation of projects by the EIB and the Commission should be intensified and expanded."

The EIB can play, and is playing, a critical role in restoring the EU's competitiveness. With a balance sheet of more than $€ 500$ billion and an annual lending volume of some $€ 70$ billion in 2013 , the EIB has an important role to play in supporting sound investment projects, both inside and outside the EU. In 2013, the EIB significantly stepped up its lending to help address the crisis in Europe. In 2014, the EIB is maintaining increased lending activity to support investment that helps economic recovery, addresses unemployment and enhances the EU's global competitiveness. To address current financial market constraints and inefficiencies in terms of risk absorption, the EIB has been developing and continues to develop tailor-made products for risk-taking and liquidity provision.

Debora Revoltella, European Investment Bank, Luxembourg, Luxembourg.
At the same time, it provides advisory services to catalyse the investment Europe needs. 